-1
$\vdots$
$\vdots$
$\vdots$

This report was poTICE

This report was prepared as an account of work sponsored by the United States Government. Neither the United States nor the United States Energy Research and Development Administration, nor any of their employees, nor any of their contractors, subcontractors, or their employees, makes any subcontractors, or their employees, makes any
warranty, express or implied, or assumes any legal liability or responsibility for the accuracy, completeness or usefulness of any information, apparatus, product or process disclosed, or represents that its use would not infringe privately owned rights.

\section{(w) Astronuclear Laboratory}

WANL-TMI-1910

May 21,1968

\title{
MODIFICATIONS IN THE HYDROGEN GAS SUPPLY \\ FOR LOW TEMPERATURE OPERATION
}

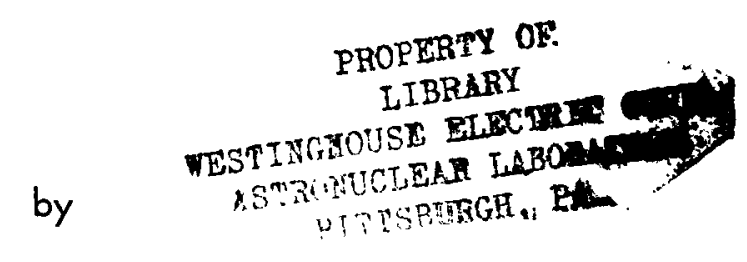

\author{
E. A. DeZubay
}

Thermo-Flow Laboratory

Reactor Engineering

\section{DISTRIBUTION}

Dr. W. H. Esselman

Mr. W. G. Roman

Mr. F. D. Retallick

Mr. J. G. Gallagher

INFORMATION CATEGORY

Mr. K. L. Rieke

Mr. W. J. Havener

Mr. H. J. Fix

Mr. L. A. Salvador

Mr. R. L. Ramp

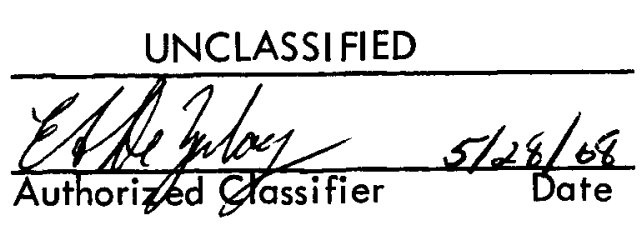




\section{DISCLAIMER}

This report was prepared as an account of work sponsored by an agency of the United States Government. Neither the United States Government nor any agency Thereof, nor any of their employees, makes any warranty, express or implied, or assumes any legal liability or responsibility for the accuracy, completeness, or usefulness of any information, apparatus, product, or process disclosed, or represents that its use would not infringe privately owned rights. Reference herein to any specific commercial product, process, or service by trade name, trademark, manufacturer, or otherwise does not necessarily constitute or imply its endorsement, recommendation, or favoring by the United States Government or any agency thereof. The views and opinions of authors expressed herein do not necessarily state or reflect those of the United States Government or any agency thereof. 


\section{DISCLAIMER}

Portions of this document may be illegible in electronic image products. Images are produced from the best available original document. 


\section{INTRODUCTION}

This memorandum considers the possibilities of slightly modifying the gas resources that we have available both at WANL and WANHES so that low temperature gas can be provided to the test cells for experiments with tie tube clusters and with fuel elements. Low temperature gas is defined in the range from $40^{\circ} \mathrm{R}$ to $200^{\circ} \mathrm{R}$. The basic devices for producing cold gas are now available. Two Paul and one Linde vaporizer units, each consisting of a pump and gas heater, accept liquid hydrogen at a level slightly above atmospheric pressure (B. $P . \cong 40^{\circ} R$ ), and compress the liquid to a fluid in the supercritical region at a temperature ranging from 80 to $100^{\circ} \mathrm{R}$. The exact temperature rise depends on the particular unit and its particular mode of operation. These units are approximately the same size. The capacity is approximately $75,000 \mathrm{SCFH}$ or 0.10 pps of hydrogen. Another available unit, made by Cryosonics, is not considered in this discussion because of its small size. The eventual disposition of these units will be that one Paul unit will be located at WANL and one Paul unit and the Linde unit will be located at WANHES. Hence, the capacity of WANHES will be approximately twice of that of WANL; namely, 0.20 pps or 150,000 SCFH.

The source of the low temperature gas is the supercritical gas emerging from the pump in the range of $100^{\circ} \mathrm{R}$. At present this cold gas passes through an electrically or air heated heat exchanger, and emerges from this heat exchanger at a temperature of approximately $500^{\circ} \mathrm{R}$. At this temperature, the gas can be discharged into the storage tubes. The presently installed system is so arranged that gas can be supplied to the test cell from the exit of the vaporizer unit or the storage tanks, individually or in combination. The simplified schematic flow diagram is shown on Figure 1. The vaporizer and the gas storage tube bank are both connected to the test cell supply line by suitable valving. The following modes of operation are possible:

1. The vaporizer charges the storage tubes.

2. The vaporizer charges the storage tubes and simultaneously supplies the test cell.

3. The storage tube bank supplies the test cells with the vaporizer not operative. 


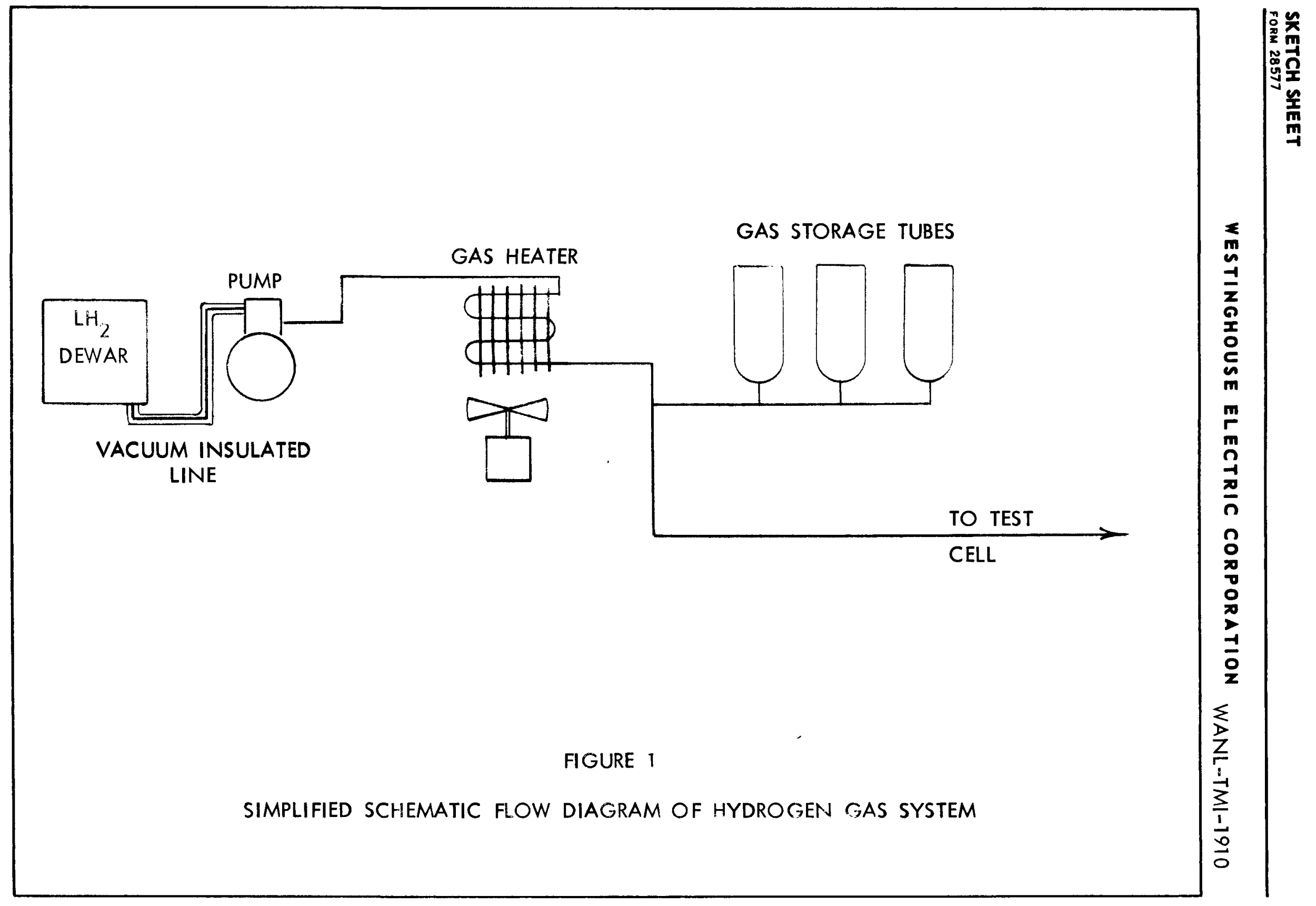


In order to supply the test cell with low temperature gas, an evolutionary scheme in two phases is developed which would provide a cold gas source at the test cells at a temperature approximating the discharge from pump and prior to the gas heater.

\section{MODIFICATIONS TO EXISTING SYSTEMS}

The initial modifications which can be incorporated in the existing gas systems at both WANL and WANHES can be done simply and relatively quickly. These changes would feature the following:

1. Constant low temperature gas at the test cell regardless of test flow requirements.

2. No waste of cold high pressure gas.

The method of accomplishing these requirements differs slightly from WANL to WANHES, but has the same basic approach. The method of providing the cold gas is by the insertion of a flow and return loop between the pump and the gas heater. Figure 2 schematically shows this insertion. The low temperature gas on discharge from the pump is lead by an insulated line to the test cell and returned by a non-insulated line to the gas heater through a pressure reducing valve. Such an arrangement would insure constant flow and pressure at the exhaust of the pump. Under these conditions the pump discharge temperature would be constant. At steady state conditions, the available low temperature gas flow rate at the test cell would be limited to the capacity of the pump. If the required low temperature flow rate would be less than that of the pump, the remainder of the gas would be returned to the storage bank through the pressure reducer for storage, and/or ambient discharge.

Preliminary calculations indicate that at the flow rate of the WANL vaporizer, the temperature rise for the $500 \mathrm{ft}$. of pipe to the test cells would be less than $50^{\circ} \mathrm{R}$ for well insulated pipe. This pipe need not be vacuum jacket, only foam insulation covered to a radial thickness of 2 to 3 inches depending on the type of insulation. Such an installation would provide a temperature of about $150^{\circ} \mathrm{R}$ at the test cell. This gas would also be at a pressure of approximately 2500 psia. A small reduction in temperature could be expected from the 


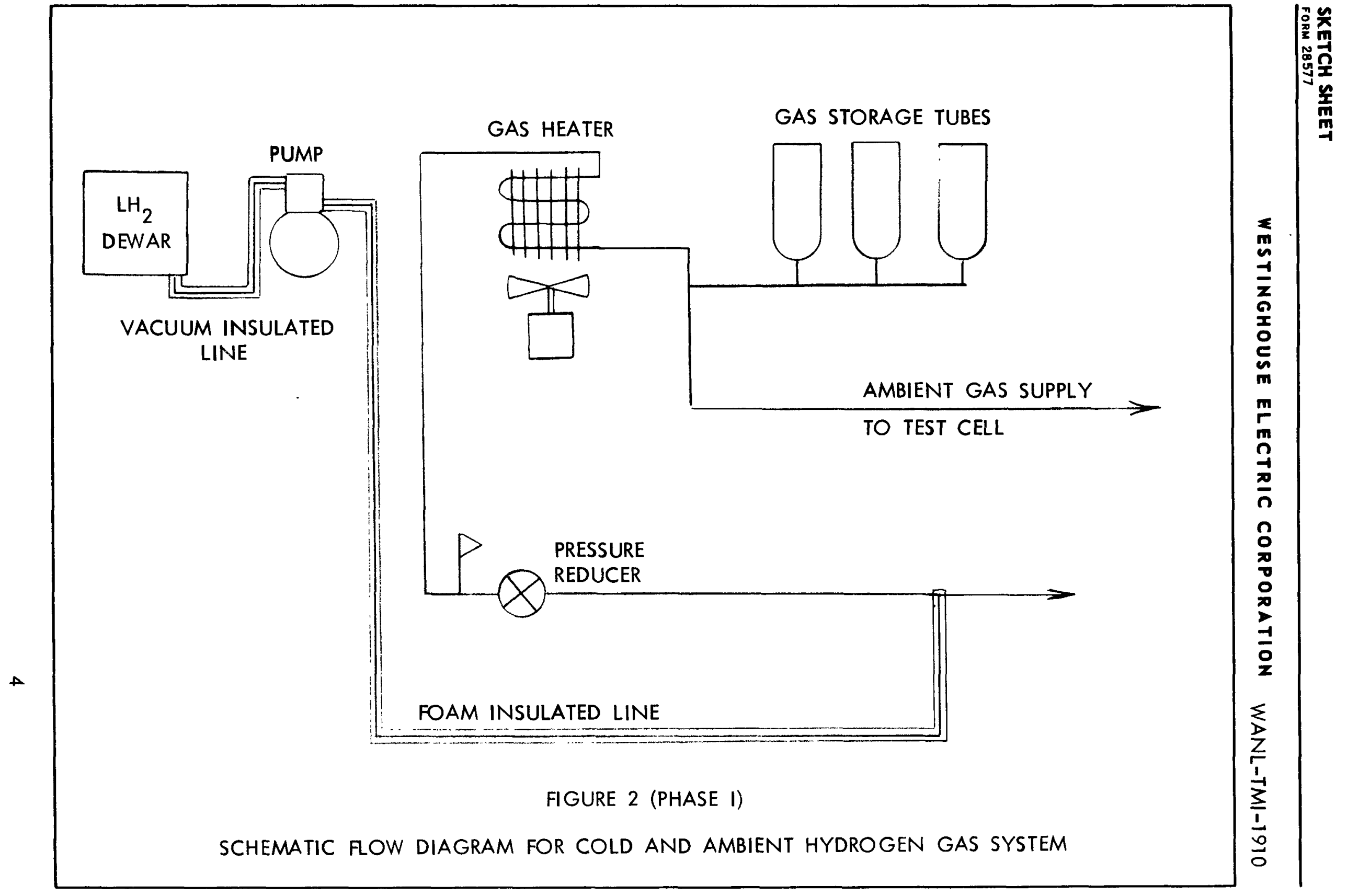


Joule Thompson effect. This reduction in temperature is shown on Figure 3, where the temperature change at constant enthalpy during an expansion from 2500 psia to 800 psia. This effect is rather small.

The additional piping required for such an installation is quite modest. Since an existing line is already available, only two additional lines would be required, one bare and one foam insulated. Additional temperature reductions could be accomplished as shown in Figure 4, where a heat exchanger and an additional low pressure cryogenic line would be required. This additional modification (considered as Phase II) would require the installation of a counterflow high pressure gas to liquid hydrogen heat exchanger at the test cell. The liquid side would be supplied directly from the dewar. The cryogenic line of approximately 500 feet is available from the 1500 feet of GFE line obtained with the 20,000 gallon dewar. Such an arrangement would permit temperature to approach $40^{\circ} \mathrm{R}$ at the test cell inlet, but would require the use of approximately $0.20 \mathrm{pps}$ of liquid hydrogen as refrigerant.

The situation at WANHES is even more favorable since one of the vaporizers, the Linde unit, at its present location, is less than 100 feet from the test cell and would be less than $\mathbf{3 0 0}$ feet from the test cell presently planned for construction. Under these conditions, the delivery temperature would be less than the estimated $150^{\circ} \mathrm{R}$ at WANHES by 20 to $40^{\circ} \mathrm{R}$. The liquid hydrogen coolant requirements for Phase II would also be less, probably no higher than 0.15 pps. A liquid hydrogen transfer line of about 500 feet would be required from the 20,000 gallon dewar to the 2700 gallon dewar supplying the Linde vaporizer. This transfer line is also available from the GFE stock.

\section{$\underline{\text { SUMMARY }}$}

These modifications would provide a low cost source of low temperature gas quickly and easily in time for significant experiments on $\mathrm{R}-1$ cluster and fuel element tests. Furthermore, these schemes utilize any overage of gas used for chill-down of the transfer lines from the pump to the test cells by returning this gas through standardized and existing equipment 
WANL-TMI-1910
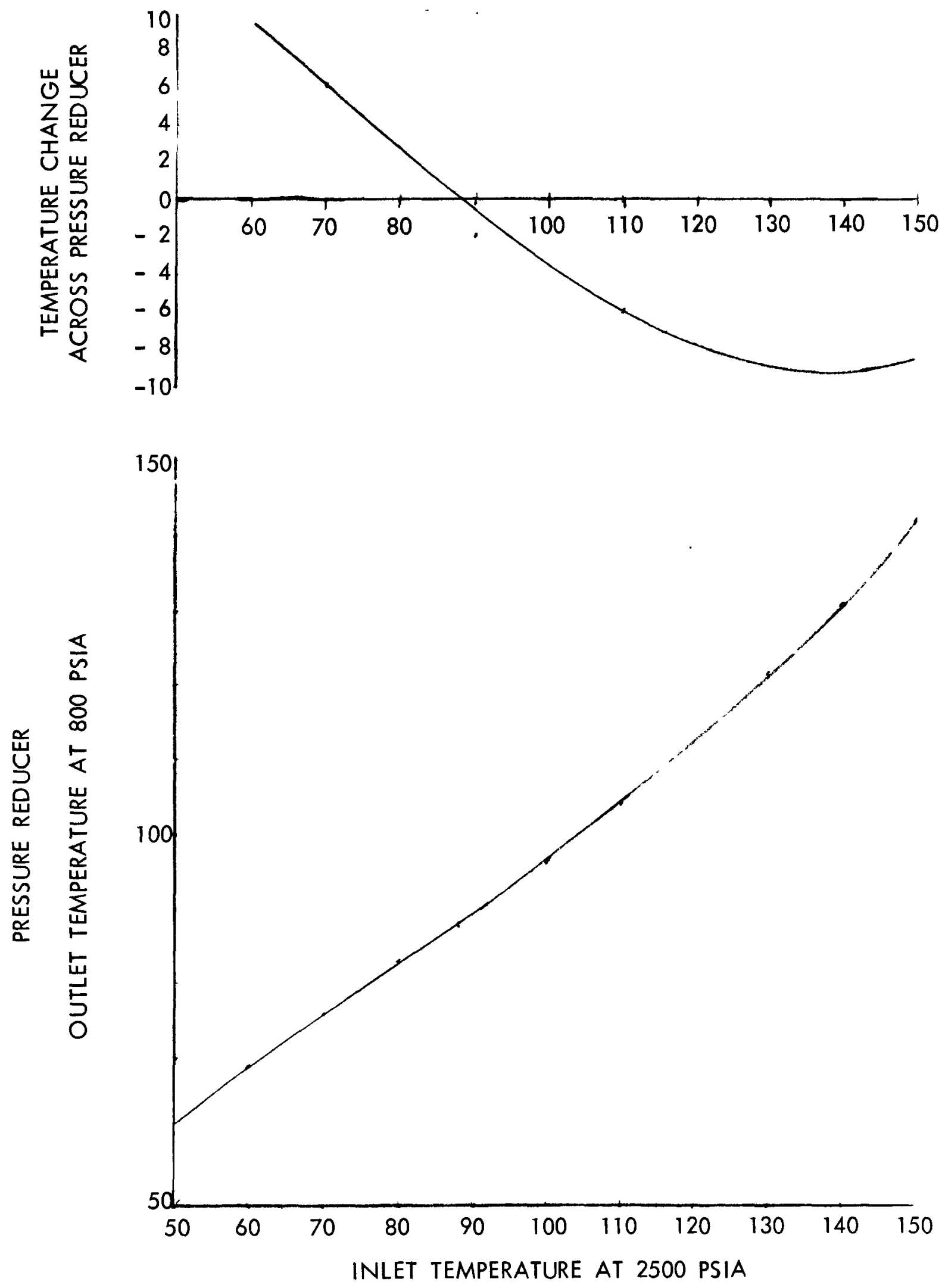

FIGURE 3 


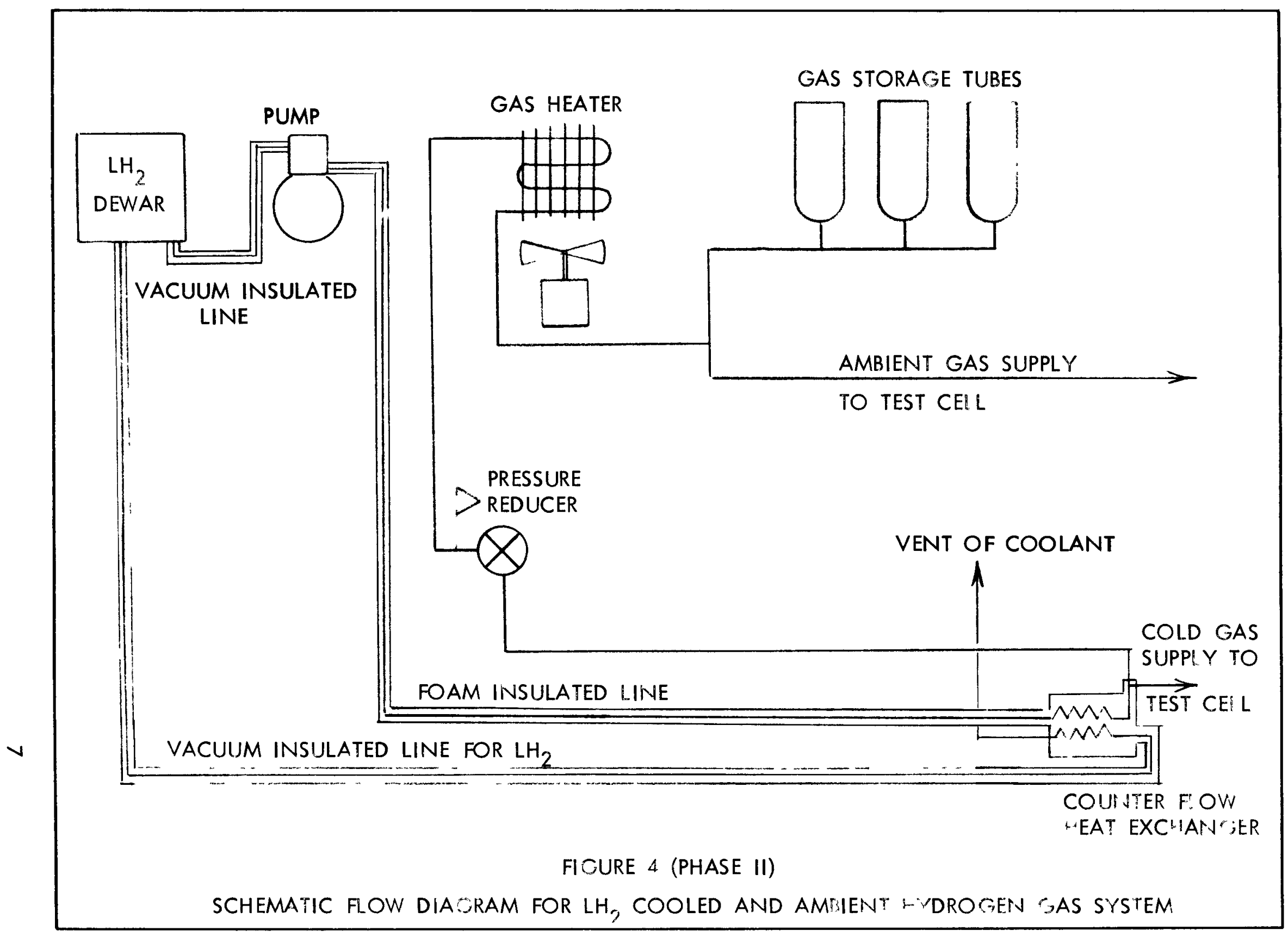

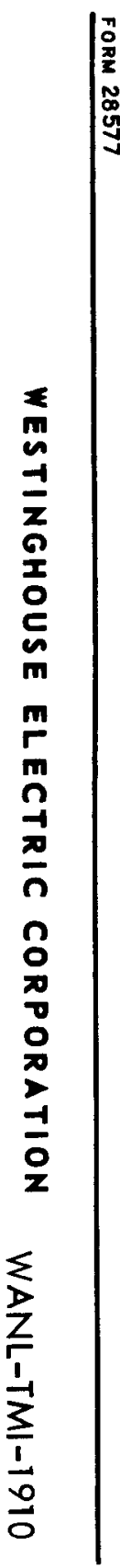


to the storage bank. The flow rates will be sufficient to supply full flow for single fuel element tests up to 0.1 pps (1200 SCFM) and for the separate flow required in stem type clusters. The main flow in the clusters will still require ambient gas. 